\title{
STORY AND DISCOURSE
}

Narrative Structure

in Fiction and Film 


\section{ALSO BY SEYMOUR CHATMAN}

Coming to Terms: The Rhetoric of Narrative in Fiction and Film Essays on the Language of Literature (edited with Samuel Levin) The Later Style of Henry James

Literary Style: A Symposium (edited and translated)

$A$ Theory of Meter 


\section{STORY AND DISCOURSE}

Narrative Structure in Fiction and Film

\section{by SEYMOUR CHATMAN}

Cornell University Press ITHACA AND LONDON 


\section{Copyright $(\mathcal{C} 1978$ by Cornell University}

All rights reserved. Except for brief quotations in a review, this book, or parts thereof, must not be reproduced in any form without permission in writing from the publisher. For information, address Cornell University Press, Sage House, 512 East State Street, Ithaca, New York 14850.

First published 1978 by Cornell University Press

First printing, Cornell Paperbacks, 1980

Acknowledgment is made for:

Excerpts from Nausea by Jean-Paul Sartre, translated by Lloyd Alexander, copyright (C) 1964 by New Directions Publishing Corporation. All rights reserved. First published in Great Britain in 1962 by Hamish Hamilton Ltd. Reprinted by permission of New Directions Publishing Corporation and Hamish Hamilton Ltd.

Excerpts from Lolita by Vladimir Nabokov, copyright (C) 1955 by Vladimir Nabokov; reprinted by permission of G. P. Putnam's Sons and Weidenfeld \& Nicolson.

A selection from The Seance and Other Stories by Isaac Bashevis Singer, copyright (C) 1965, 1968 by Isaac Bashevis Singer; reprinted with the permission of Farrar, Straus \& Giroux, Inc., and Jonathan Cape Ltd.

Excerpts from Mrs. Dalloway by Virginia Woolf, copyright 1925 by Harcourt Brace Jovanovich, Inc.; renewed 1953 by Leonard Woolf. First published 1925 by The Hogarth Press. Reprinted by permission of the publishers.

Excerpts from "The Garden of Forking Paths" from Fictions by Jorge Luis Borges, translated by Anthony Kerrigan; copyright (C) 1962 by Grove Press, Inc.; (C) 1956 by Emece Editores, S.A., Buenos Aires; reprinted by permission of Grove Press, Inc., and Weidenfeld \& Nicolson.

Excerpts from Two Novels: Jealousy by Alain Robbe-Grillet, translated by Richard Howard; copyright (C) 1959 by Grove Press, Inc., reprinted by permission of Grove Press, Inc., and John Calder Ltd.

Excerpt from The Four Gated City by Doris Lessing, copyright (C) 1969 by Doris Lessing Productions Ltd; reprinted by permission of Alfred A. Knopf, Inc., and James Brown Associates.

Excerpt from "The Idol of the Cyclades" from End of the Game and Other Stories by Julio Cortàzar, translated by Paul Blackburn; copyright (C) 1967 by Random House, Inc.; reprinted by permission of Pantheon Books, a division of Random House, Inc.

\section{Library of Congress Cataloging in Publication Data}

(For library cataloging purposes only)

Chatman, Seymour Benjamin, 1928-

Story and discourse.

Includes bibliographical references and index.

1. Arts 2. Narration (Rhetoric) I. Title.

NX650.N37C45 700'.1 78-9329

ISBN-13: 978-0-8014-9186-3 (pbk. : alk. paper)

ISBN-10: 0-8014-9186-X (pbk. : alk. paper)

Paperback printing 20191817161514131211 
For Elaine 
